\title{
THE EFFECTIVENESS OF GIVING PINEAPPLE AND CORN PUDDING ON THE REDUCTION OF URIC ACID LEVELS IN THE WORKING AREA PUSKESMAS SOSIAL PALEMBANG CITY
}

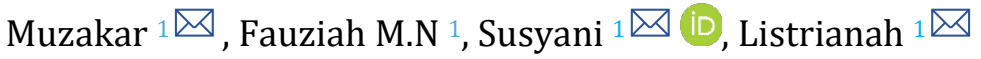 \\ ${ }^{1}$ Jurusan Gizi, Politeknik Kementerian Kesehatan Palembang, Jl. Sukabangun I No. 3623 KM. 5,5 Palembang \\ 30151, Indonesia.
}

Received 6 November 2021

Accepted 17 December 2021

Published 31 December 2021

\section{CorrespondingAuthor}

Muzakar,

zackmuba@yahoo.co.id

DOI

10.29121/granthaalayah.v9.i12.2021 .4441

Funding: This research received no specific grant from any funding agency in the public, commercial, or not-for-profit sectors.

Copyright: (C) 2021 The Author(s). This is an open access article distributed under the terms of the Creative Commons Attribution License, which permits unrestricted use, distribution, and reproduction in any medium, provided the original author and source are credited.

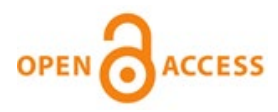

\section{ABSTRACT}

Background: Gout is a failure of purine metabolism that causes an increase in the concentration of uric acid in the blood. The prevalence of gout in Indonesia in 2018 was $7.3 \%$ and in South, Sumatra was $62.4 \%$. One of the non-pharmacological managements of gout is by giving pineapple and corn pudding.

Purpose: This study was to determine the effect of pineapple and corn pudding on the decrease in blood uric acid levels in hyperuricemia patients.

Method: The type of research is a quasi-experiment with a pretest and posttest control group design. This research was conducted from January to February 2021 at the Puskesmas Sosial Palembang City. The research sample was selected by accidental sampling with a total sample of treatment and comparison groups of each of 30 respondents.

Result: Data analysis using paired sample t-test and independent sample t-test with the difference in the average value of uric acid levels of the treatment group $0.7 \mathrm{mg} / \mathrm{dl}(\mathrm{p}$ value $=0.011)$ and the comparison group $0.44 \mathrm{mg} / \mathrm{dl}(\mathrm{p}$-value $=0.049)$. While the results of the independent sample t-test are $\mathrm{p}$-value $=0.003$.

Conclusion: Statistical test results showed that there was an effect of pineapple and corn pudding on the decrease in blood uric acid levels in hyperuricemia patients with differences in the average difference in blood uric acid levels in the treatment group higher than the comparison group.

Keywords: Uric Acid, Hyperuricemia, Pineapple, and Corn Pudding.

\section{INTRODUCTION}

Gout is a failure of purine metabolism which causes an increase in the concentration of uric acid in the blood (hyperuricemia) Damayanti (2012). Although gout is not a deadly disease, it is very annoying and dangerous. Pain arises in the patient, it can interfere with activities (Herliana, 2013).

World Health Organization (WHO) (2018), the prevalence of gout has increased by 1370 (33.3\%). The prevalence of gout also increased among adults in the UK by $3.2 \%$ and the United States by 3.9\% (Kuo; Grainge; Zhang; Doherty, 2015). In Korea, the prevalence of uric acid increased from $3.49 \%$ per 1000 people in 2007 to $7.58 \%$ per 1000 people in 2015 (Kim; Kwak; Lee; Choe; Park, 2017). Then the annual incidence of gout was $2.68 \%$ per 1000 people, with men 2-6 folds more at risk than women. The incidence of gout worldwide can gradually increase due to bad habits such as fast food, lack of exercise, increased incidence of obesity, and metabolic syndrome (Ragab et al., 2017). 
Based on the results of the 2018 Riskesdas, the prevalence of hyperuricemia based on diagnosis in Indonesia was 7.3\%. The highest prevalence of disease was in Aceh with $13.3 \%$, and the lowest was in West Sulawesi with 3.2\%. The prevalence of joint disease in South Sumatra is below 7.3\%. The prevalence of patients with gout based on age, namely, age $15-24$ years with a diagnosis is $1.2 \%$, age $25-34$ years with a diagnosis is $3.1 \%$, and age $35-44$ years with a diagnosis is $6.3 \%$, age $45-54$ years based on diagnosis is $11.1 \%$, age $55-64$ years based on diagnosis is $15.5 \%$, age 65 74 years based on diagnosis is $18.6 \%$, and age 75 years or more is $18.9 \%$. More people in rural areas have gout based on diagnosis, namely $7.8 \%$ compared to

Hyperuricemia sufferers in Palembang in 2014 were 62.4\% (Palembang City Health Office, 2014). The prevalence of hyperuricemia sufferers in Palembang Social Puskesmas in 2016 was 25.2\% (Palembang City Health Office, 2016). The prevalence of gout sufferers at the Palembang Social Puskesmas in 2019 was 22.8\%.

Non-pharmacological management or traditional medicine that can reduce uric acid levels in the long term does not cause harmful side effects, one of which is pineapple to reduce uric acid levels. Pineapple contains an enzyme called bromelain, which is known to reduce inflammation and aid digestion. Although there are no studies that directly link bromelain to gout, Trusted Source research suggests that bromelain supplements can reduce inflammatory symptoms of gout.

Bromelin is one of the enzymes found in pineapples. The enzymes that have high enough levels in pineapples have many benefits for the health of the human body. Bromelain enzyme is a protase enzyme in pineapple that can increase blood circulation in the body which makes uric acid crystals easier to break down so that uric acid levels in the blood decrease. Bromelin is a protease enzyme that hydrolyzes the peptide bonds in proteins into smaller molecules, namely amino acids, so that they are easily digested by the body. Bromelin contains the enzymes amylase, cellulase, acid phosphatase, and acid peroxidase in very small amounts. Bromelin content in pineapple pulp is 0.080-0.125 (Ferdiansyah., 2005).

The content of Vitamin $C$ in pineapple is very high. A study has shown that taking $500 \mathrm{mg}$ of vitamin $\mathrm{C}$ over a period of 2 weeks can reduce uric acid levels by an average of $10 \%$. This is in line with research conducted by Choi from the University of British Columbia on 4,694 men (1986-2006). During that time, there was a decrease in 1,317 men suffering from uric acid. Giving vitamin $\mathrm{C}$ of $500 \mathrm{mg}$ per day can reduce the risk of gout by $17 \%$. The function of vitamin $C$ itself can help increase uric acid excretion through urine, so those uric acid levels in the body are reduced (Sutanto, 2013). In corn, there is a high content of vitamins, minerals, and fiber. Consuming boiled corn can help reduce uric acid levels in the body as well as make joints cleaner from uric acid crystals. This can help significantly reduce the frequency of gout attacks. In corn, there are ingredients that can stimulate the formation of osteoblasts substances, substances that form bone cells. This content can also help prevent the buildup of uric acid in the joints (2018 Team Dr.).

Potassium is a mineral substance that is contained in many foods. Therefore, meeting the daily intake of potassium is actually not difficult. The recommended potassium intake is 3,500-4,700 mg per day. Based on the theory put forward by Utari (2020), the benefits of potassium also play a role in reducing the risk of stroke, gout, lowering blood pressure, keeping the body from losing muscle mass, maintaining bone density, and reducing the risk of kidney stone formation. Consuming foods rich in potassium can reduce the amount of calcium wasted through urine. In a study involving 62 elderly women (45-55 years), researchers 
found that respondents who consumed more potassium had the largest total bone mass.

\section{METHOD}

The type of research used is quantitative research with a quasi-experimental design. The design in this study used a pre-test and post-test with a control design. The design used was a pretest-posttest design using a comparison group. The treatment group was given pineapple and corn pudding while the comparison group was given placebo mango flavored pudding.

The research was conducted from January to February 2021 in the Work Area of the Social Puskesmas in Palembang City. The population in this study were all patients with gout in the Palembang Social Puskesmas Working Area. Sampling using an accidental sampling technique based on a chance/ incidental meeting with the researcher can be used as a sample if, in the view of the person who happened to be met, it is suitable as a data source. The sample size in the study was calculated using the proportion estimation formula from Lameshow (1990) with a total of 60 respondents, each group of 30 people.

\section{RESULTS}

Characteristics of respondents consisting of gender, age, nutritional status, and physical activity are presented in Table 1, the average uric acid levels before the intervention in the treatment group and the comparison group are presented in Table 2, the average uric acid levels after the intervention in the treatment group and comparison groups are presented in Table 3, differences in uric acid levels before and after treatment are presented in Table 4, the treatment group was the group of respondents who were given pineapple and corn pudding and uric acid medicine, while the comparison group was given placebo mango flavor syrup pudding and gout medicine.

\begin{tabular}{|c|c|c|c|c|}
\hline \multirow[t]{2}{*}{ Characteristics of Respondents } & \multicolumn{2}{|c|}{ Treatment } & \multicolumn{2}{|c|}{ Comparison } \\
\hline & n & $\%$ & n & $\%$ \\
\hline \multicolumn{5}{|l|}{ Gender } \\
\hline Male & 8 & 26,7 & 14 & 46,7 \\
\hline Female & 22 & 73,3 & 16 & 53,3 \\
\hline Total & 30 & 100 & 30 & 100 \\
\hline \multicolumn{5}{|l|}{ Age } \\
\hline $35-45$ & 9 & 30,0 & 12 & 40,0 \\
\hline $45-55$ & 13 & 43,3 & 12 & 40,0 \\
\hline $55-65$ & 8 & 26,7 & 6 & 20,0 \\
\hline Total & 30 & 100 & 30 & 100 \\
\hline \multicolumn{5}{|l|}{ Nutritional status } \\
\hline Normal & 14 & 46,7 & 16 & 53,3 \\
\hline Overwight & 6 & 20,0 & 7 & 23,3 \\
\hline Obesity & 10 & 33,3 & 7 & 23,3 \\
\hline Total & 30 & 100 & 30 & 100 \\
\hline \multicolumn{5}{|l|}{ Physical Activity } \\
\hline Heavy & 21 & 70,0 & 14 & 46,7 \\
\hline Moderate & 9 & 30,0 & 16 & 53,3 \\
\hline
\end{tabular}




Total $30 \quad 100 \quad 30 \quad 100$

\begin{tabular}{|ccccc|}
\hline \multicolumn{4}{|c|}{ Table 2 Average Uric Acid Levels Before Intervention } \\
\hline \multicolumn{2}{|c}{ Group } & The Number of Samples & Uric Acid Levels & Average \\
\hline Treatment & 60 & Highest & Lowest & \\
Comparison & & 12,0 & 6,1 & 7,6 \\
\hline
\end{tabular}

\begin{tabular}{|ccccc}
\hline Table 3 & Average Uric Acid Levels After Intervention \\
\hline Group & The Number of Samples & Uric Acid Levels & Average \\
\hline Treatment & 60 & Highest & Lowest & \\
Comparison & & 9,8 & 5,4 & 6,9 \\
\hline
\end{tabular}

\section{Bivariate Analysis}

Table 4 Differences in uric acid levels before and after treatment ( $t$-dependent test)

\begin{tabular}{|ccccc|}
\hline Group & Initial mean \pm SD & Final mean \pm SD & t & p-value \\
Treatment & $7,6 \pm 1,080$ & $6,9 \pm 1,232$ & 2,736 & 0,011 \\
Comparison & $7,49 \pm 0,886$ & $7,93 \pm 1,252$ & 2,054 & 0,049 \\
\hline
\end{tabular}

Table 5 Differences in uric acid levels before and after treatment (independent t-test)

\begin{tabular}{|ccccc|}
\hline Group & $\mathbf{n}$ & Mean \pm SD & t & p-value \\
Treatment & 60 & $6,97 \pm 1,131$ & 3,115 & 0,003 \\
\hline Comparison & & $7,93 \pm 1,242$ & & \\
\hline
\end{tabular}

\section{DISCUSSION}

\section{1) Respondent characteristics based on age and gender}

The characteristics of the respondents in this study were mostly female, namely 38 people $(63.3 \%)$ with an age range of mostly $45-55$ years, namely $41.6 \%$ in each group.

Based on research conducted by Setiawan MA, et al (2019), increasing age is an important risk factor for men and women. This is probably due to many factors, such as increased serum uric acid levels (the most common cause is decreased kidney function), increased use of diuretic drugs, and other drugs that can increase serum uric acid levels.

On average, $90 \%$ of patients who experience uric acid above normal are 30-50 years old. The increase in uric acid levels occurs due to decreased kidney function in the excretion of metabolic waste in the body which is characterized by high levels of urea and creatinine. The decline in kidney function that occurs causes uric acid to increase from normal values (Nurjaknah, 2015). However, this is not in line with the research conducted, where the results obtained were most of those aged 45-55 years.

The development of gout arthritis before the age of 30 is more common in men than in women. However, the incidence of gout arthritis is the same between the 
sexes after 60 years of age. However, women are at increased risk of gouty arthritis after menopause at age 45 due to a decrease in the hormone estrogen. This causes gouty arthritis rarely in young women Firdayanti (2019).

In general, men are more likely to suffer from uric acid, and it will tend to increase with age. Meanwhile, in women the percentage is smaller, where the increase tends to run since the onset of menopause. This is because women have the hormone estrogen which helps remove uric acid through urine. In men, uric acid is higher because they do not have the hormone estrogen. So as long as a woman has the hormone estrogen, her uric acid disposal is controlled (Syarif, 2012).

The effect of estrogen on uric acid in the blood is associated with uric acid excretion via the kidneys. Excretion of uric acid in women who still produce estrogen can increase and uric acid levels in the blood can be normal, but in women who are no longer producing estrogen, uric acid excretion is not helped and can cause hyperuricemia. Estrogen increases renal uric acid excretion, specifically estradiol-type estrogen which suppresses the protein levels of URATI and Glu9 so that it increases uric acid excretion from the blood through the kidneys so that hyperuricemia does not occur Moriwaki (2014).

The results of this study were that high uric acid levels were more common in women, this was because men did not have the hormone estrogen, while women had the hormone estrogen which functions as a uricosuric agent, a chemical that helps uric acid excretion through the kidneys (Setyoningsih)., 2017).

\section{2) Characteristics of Respondents based on Nutritional Status}

Purwaningsih (2009) suggests that someone who is overweight usually has a diet that is more than what he or she needs. In this diet, it is also possible that excessive purine intake also occurs in addition to carbohydrate, protein, and fat intake. In addition, excess weight causes stress on the joints, so that uric acid is difficult to excrete in the body and also triggers insulin resistance. However, this is not in line with the research conducted, where most respondents have a nutritional status with a normal BMI.

In respondents with a normal BMI, high uric acid levels can be caused by high purine intake. However, overweight individuals (overweight and obese BMI status) are caused by high-fat deposits. High-fat stores are associated with insulin resistance and individual components of the metabolic syndrome including hypertension, dyslipidemia, and associated with uric acid status. (Augne, D. \& Vatten, L.J (2014)).

Fat can inhibit the removal of uric acid through the kidneys. Burning fat in order to meet calorie needs such as occurs in a state of hunger, strict diet, or uncontrolled diabetes mellitus will increase ketone levels in the blood, and this situation will cause ketosis. Ketones that are formed from burning fat will inhibit the release of uric acid through the kidneys. As a result, uric acid levels in the blood increase Dalimartha (2008).

\section{3) Characteristics of Respondents Based on Physical Activity}

In anaerobic activity, the energy that will be used by the body to perform activities that require energy quickly will be obtained through the hydrolysis of phosphocreatine (PCR) and) and through anaerobic glucose glycolysis. This anaerobic energy metabolism process can run in the absence of oxygen (02). The glycolysis process that occurs in the cell cytoplasm will convert glucose molecules 
into pyruvic acid where this process will also be accompanied by the formation of ATP. Pyruvic acid molecules that are formed from the glycolysis process can undergo further metabolic processes both aerobically and anaerobically depending on the availability of oxygen in the body.

When exercising at a low intensity where the availability of oxygen in the body is large enough, the pyruvic acid molecules that are formed can be converted into $\mathrm{CO} 2$ and $\mathrm{H} 2 \mathrm{O}$ in the mitochondria of cells. If the availability of oxygen is limited in the body or when pyruvic acid is formed rapidly, the pyruvic acid will be converted to lactic acid. The more strenuous physical activity that is carried out and lasts for the long term, the more lactic acid is produced. An excessive increase in lactic acid will cause it to stick to the blood vessels and will cause uric acid to stick to the lactic acid. So those increasing levels of lactic acid in the blood will disrupt uric acid excretion (Pursriningsih \& Panunggal 2015).

This is also supported by the theory of Ilyas (2014) which states that physical activity is a cause that can increase blood uric acid levels due to the production of lactic acid during activities, especially strenuous physical activity.

\section{4) The Effect of Pineapple and Corn Pudding on Decreasing Uric Acid Levels}

This study involved 60 respondents consisting of 30 respondents in the treatment group and 30 respondents in the comparison group. In the treatment group, pineapple and corn pudding gave for 7 consecutive days while the comparison group was given placebo pudding with mango flavor syrup for 7 consecutive days.

The statistical test results obtained by p-value $=0.003$ means $5 \%$ alpha, which can be concluded that there is an effect of giving pineapple and corn pudding on uric acid in patients with uric acid levels who have a decrease in uric acid levels by 0.6 mg dl.

Pineapple fruit contains vitamin $\mathrm{C}$ which is very high. This vitamin works by helping the kidney-related systems excrete more uric acid. In addition, it is also useful to keep purines from being produced into uric acid (Sevilia \& Dwiningtyas, 2014). Pineapple fruit also contains flavonoids as antioxidants so that it can inhibit the action of the xanthine oxidase enzyme which can cause the metabolism of purines that form uric acid not to occur (Deviandra et al., 2013). In addition, the bromelain enzyme found in pineapple has proven to be effective as an antiinflammatory and analgesic for hyperuricemia sufferers (Putri \& Anita, 2017).

Based on the theory put forward by Utari (2020), the benefits of potassium also play a role in reducing the risk of stroke, gout, lowering blood pressure, keeping the body from losing muscle mass, maintaining bone density, and reducing the risk of kidney stone formation. Consuming foods rich in potassium can reduce the amount of calcium wasted through urine. In a study involving 62 elderly women (45-55 years), researchers found that respondents who consumed more potassium had the largest total bone mass. 


\section{CONCLUSION}

Based on the results of research that has been carried out on hyperuricemia patients at the Puskesmas Sosial Palembang City, the following conclusions can be drawn:

1) Most of the samples were female as much as $63.4 \%$, samples aged $45-55$ years were $41.7 \%$, samples with normal nutritional status were $50 \%$ and obesity was $28.3 \%$, samples with moderate physical activity were $58.3 \%$.

2) Most of the samples had $100 \%$ good purine intake, $71.6 \%$ good Vitamin $C$ intake, $70.0 \%$ good Bromelin intake, and $78.3 \%$ good potassium intake

3) The average uric acid level of hyperuricemia patients in the treatment group before intervention was $7.6 \mathrm{mg} / \mathrm{dL}$ and after intervention was 6.9 mg / dL. The difference in decreasing uric acid levels in patients with hyperuricemia in the treatment group was $0.7 \mathrm{mg} / \mathrm{dL}$.

4) There is a difference in the average uric acid levels in the treatment and comparison groups after giving pineapple and corn pudding, analyzed by $\mathrm{t}$-dependent test. The results of statistical tests ( $\mathrm{t}$-dependent test) obtained $\mathrm{p}$-value $<0.05(\mathrm{p}=0.011)$, so it can be concluded that there is an effect of pineapple and corn pudding on reducing uric acid levels.

5) There was an effect of pineapple and corn pudding on reducing uric acid levels in the treatment group analyzed by independent t-test. The results of statistical tests obtained p-value $=0.003$ means $5 \%$ alpha shows a significant comparison of the average uric acid levels in the treatment group given pineapple and corn pudding and the comparison group given mango syrup flacebo pudding.

\section{SUGGESTION}

1) Respondents are expected to continue consuming pineapple and corn pudding to reduce uric acid levels and can be used as additional information for the public in providing non-pharmacological therapies and the use of pineapple and corn on uric acid levels in gout sufferers.

2) For health centers, it is hoped that this researcher can be used as input and information that pineapple and corn pudding can be used as an ingredient for counseling and therapy for hyperuricemia sufferers.

3) For researchers, it is hoped that this research can add and develop knowledge and insight in the field of clinical nutrition in the provision of pineapple and corn pudding to hyperuricemia sufferers.

4) For the Health Polytechnic of the Ministry of Health, Department of Nutrition, Palembang, it is hoped that this research can be used to add to the literature on reducing uric acid levels in patients with hyperuricemia.

5) The next researchers, it is hoped that this research can be continued by adding the bromelain enzyme Lab test.

\section{REFERENCES}

Anon. (2018). "Faktor-Faktor Yang Berhubungan Dengan Kejadian Asam Urat Pada Usia 20-44 Tahun Di RSUD Bahteramas Provinsi Sulawesi Tenggara Tahun 2017." 1-6 
Anon. (2018). "Pengaruh Pemberian Jus Nanas terhadap Perubahan Kadar Asam Urat Di Desa Keniten Kecamatan Geneng Kabupaten Ngawi."

Anon. (2018). "WHO Methods and Data Sources for Global Burden of Disease Estimates." (June).

Ariani. A.R \& Nurbaya. E., (2019). Effects of pineapple (Ananascomocus (L.) Merr) extract tolower uric acid levels in hyperurismic in malerats

Ariev dkk, (2013). New Data On Gout and Hiperurisemia : Insidence Rates, Risk Factors and Aging-Associated Manifestations. (Journal). Russia: Mechnikov North West State Medical University Vol. 3 No. 2 Retrieved from https://doi.org/10.1134/S2079057013020021

Bitik Berivan \& Ozturk M. (2014). An old disease with new insights : Update on diagnosis and treatment of gout. European journal of rheumatology. Hal 72 Retrieved from https://doi.org/10.5152/eurjrheum.2014.021

Dalimartha, Setiawan. (2008). "Resep Tumbuhan Obat Untuk Asam Urat - Google Buku."

Damayanti, Deni. (2012). Panduan Lengkap Mencegah dan Mengobati Asam Urat. Yogyakarta : Araska

Darussalam Nutrition Journal, November (2020), 4(2) :104-111 Retrieved from https://doi.org/10.21111/dnj.v4i2,4049

Dianati, Nur Amalina. (2015). "Gout and Hyperuricemia." 4 :82-89.

Ekonomi, Sosial. n.d. (2018) "Hasil Utama Riskesdas."

Firdayanti, Susanti \& Setiawan., (2019). Perbedaan Jenis Kelamin Dan Usia Terhadap Kadar Asam Urat Pada Penderita Hiperurisemia Retrieved from file://C:/Users/lenovo/Downloads/55883-205-135195-1-1020200102.pdf

Gizi, Departemen Ilmu, Fakultas Kedokteran, and Universitas Diponegoro. (2018). "Journal of Nutrition College," 7 :54-60.

Hariadi., (2016). Hubungan Indeks Massa Tubuh Dengan Kadar Asam Urat Di Dusin Niten Nogotirto Gamping Sleman Yogyakarta

Ilmiati. L., (2017). Hubungan Asupan Purin, Vitamin C Dan Status Gizi Dengan Kadar Asam Urat Pada Lansia Di Posyandu Lansia Panjang Yuswo Kelurahan Pajang Kecamatan Laweyan Kota Surakarta

Index, Glycemic, and Sweet Corn. (2011). "Nilai Indeks Glikemik Beberapa Jenis Pengolahan Jagung Manis (Zea Mays Saccharata Sturt). “ 6(1) :36-41. Retrieved from https://doi.org/10.25182/jgp.2011.6.1.36-41

Irfan Silaban \& Soraya Rahmanisa., (2009). Pengaruh Enzim Bromelin Buah Nanas (Ananas comosus L.) terhadap Awal Kehamilan

Journal Keperawatan (J-Kp) Volume 7 Nomor 2, November (2019). Kebiasaan Makan Makanan Tinggi Purin Dengan Kadar Asam Urat Di Puskesmas Retrieved from https://doi.org/10.35790/jkp.v7i2.27476

Kesmas, Jurnal, Stikes Widya, Nusantara Palu, (2018). "Hubungan Pola Makan Dengan Terjadinya Gout (Asam Urat) Di Desa Limran Kelurahan Pantoloan Boya" 7(6).

Kowalak, Welsh \& Jennifer P.,William Brenna Mayer. (2012). Buku Ajar Patofisiologi. Jakarta : EGC

Mclaughlin., (2008), Paw-paw and Cancer Annonaceous Acetogenin from Discovery to Comercial Products, Department of Medicinal Chemistry and Molecular 
Pharmacology, School of Pharmacy and Pharmaceutical Sciences, Purdue University, $71(7)$ :1311-1321 Retrieved from https://doi.org/10.1021/np800191t

Misnadiarly. (2007). Rematik : asam urat - hiperurisemia, artritis gout. Jakarta : Pustaka Obor Populer

Moriwaki, Y. (2014). Effect on Uric Acid Metabolism of the Drugs except the Anthuperuricemics. Retrieved from https://doi.org/10.4172/jbb.1000173

Mumford S. L., Dasharathy S, S, Pollack A. Z., Perkins N, J., Mattison D. R., Cole S. R, Et al, (2013). Serum Uric acid in relation to endogenous reproductive hormones during the menstrual cycle. Retrieved from https://doi.org/10.1093/humrep/det085

Notoatmodjo, S. (2012). Metode Penelitian Kesehatan. Jakarta : Rineka Cipta.

Novita, S, (2018). Pengaruh Pemberian Jus Nanas Terhadap Penurunan Kadar Asam Urat Di Desa Keniten Kecamatan Geneng Kabupaten Ngawi.

Noviyanti. (2015). Hidup Sehat Tanpa Asam Urat. Yogyakarta.

Nurventi. N., (2019). Perbandingan Metode Analisis Logam Berat Kromium Dan Timbal Menggunakan Inductively Coupled Plasma Optical Emision Spectroscopy (ICP OES) Dan Anatomic Absorbtion Spectrometry (AAS).

Purwaningsih, Indah. (2017). "Potensi Enzim Bromelin Sari Buah Nanas (Ananas Comosus L.) Dalam Meningkatkan Kadar Protein Pada Tahu." 6(1) :2-9. Retrieved from https://doi.org/10.29238/teknolabjournal.v6i1.86

Purwaningsih, T. (2009). Faktor-Faktor Risiko Hiperurisemia. Tesis. Semarang : Universitas Diponegoro.

Rasyad, Ade Arinia. (2019). "Effects of Pineapple (Ananas Comocus (L.) Merr) Extract to Lower Uric Acid Levels in Hyperurismic in Male Rats Pengaruh Pemberian Ekstrak Nanas (Ananas Comocus (L.) Merr) Terhadap Penurunan Kadar Asam Urat Pada Tikus Jantan Hiperurisemia Intisari." 15(2) :64-69. Retrieved from https://doi.org/10.20885/jif.vol15.iss2.art2

Rina, A., Eff, Y., Rahayu, S. T., \& Syachfitri, R. D. (2016). Uji Aktivitas Penghambatan Xantin Oksidase secara In-Vitro Glukopiranosida (C 20 H 22 O 10) yang Diisolasi dari Mahkota Dewa (Phaleria macrocarpa (Scheff.) Boerl) Abstrak. 3(1). Retrieved from https://doi.org/10.7454/psr.v3i1.3213

Risa, Kristara Marta, Enik Listyaningsih, Sekolah Tinggi, Ilmu Kesehatan, and Bethesda Yakkum. n.d. "Dan Jus Nanas Pada Lansia." 002 :37-42.

Sakhaee \& Maalouf, (2012). Metabolic Syndrome and Uric Acid Nephrolithiasis, Seminars in Nephrology, Vol. 28, No. 2, pp. 174- 180. Retrieved from https://doi.org/10.1016/j.semnephrol.2008.01.010

Scarlet, D. (2018). Konsep Diet Asam Urat. Journal of Chemical Information and Modeling, 53(9).

Schumacher et al., (2014). Outcome Evaluations in Gout, Journal Rheumatol, Vol.34, No. 6, pp. 1381-1385.

Setyoningsih, R., (2009). Faktor-faktor Yang Berhubungan Dengan Kejadian Hiperurisemia Pada Pasien Rawat Jalan RSUP Dr.Kariadi Semarang

Ticinesi A, Lauretani F, Ceda GP, Ruggiero C, Ferrucci L, Aloe R, et al. Uric acid and endothelial function in elderly community-dwelling subjects 